\title{
TELEOLOGIA E VONTADE SEGUNDO HUSSERL
}

\author{
Martina Korelc*
}

\begin{abstract}
RESUMO
O texto analisa como a teleologia, forma do ser da subjetividade segundo Husserl, opera na vontade. Em primeiro lugar são apresentados os elementos fundamentais da fenomenologia da vontade enquanto posição de metas; a seguir pergunta-se sobre a meta derradeira que opera na subjetividade como o telos implicado no processo do seu ser. Husserl pensa o telos como o ideal ético infinito da subjetividade perfeita na comunidade perfeita. A fé e a decisão pessoal por esta meta são fundamentais para a realização do sentido do ser.
\end{abstract}

Palavras-chave: Fenomenologia. Teleologia. Subjetividade. Vontade. Ser.

\begin{abstract}
According to Husserl, a teleology is a form of being of transcendental subjectivity; a paper analyses how it operates in a will, by pointing out, in the first place, the fundamental elements of the phenomenology of will and, in the second place, by asking about the authentic goal of will that functions as a telos of the process of being. The telos is thought by Husserl as an infinite ethical ideal of the perfect subjectivity in a perfect community. A faith and a personal decision on this goal are necessary for the sense of being.
\end{abstract}

Keywords: Phenomenology. Teology. Subjectivity. Will. Being.

\footnotetext{
* Professora Doutora em Filosofia pela Pontifícia Universidade Católica do Rio Grande do Sul (PUC-RS). Pós-doutorado em fenomenologia de Husserl na Albert-Ludwigs Universität, Freiburg, Alemanha. Atualmente é professora adjunta de filosofia no Curso de Filosofia e no programa de Pós-graduação em Filosofia da Faculdade de Filosofia da Universidade Federal de Goiás (UFG). E-mail: comloy@uol.com.br.
} 
No presente trabalho ${ }^{1}$, pretendo apresentar sucintamente o problema da teleologia na obra de Husserl, na sua relação com a vontade. O tema da teleologia, que é conhecido, sobretudo, tal como é desenvolvido na Krisis, na sua relação com a história da filosofia, é em Husserl muito amplo e pode ser abordado - ou deveria ser, para ser devidamente compreendido - sob muitos aspectos. A tese que guia a minha leitura é que Husserl com este tema pretende responder à pergunta que orienta toda a sua investigação filosófica, a pergunta pelo sentido da existência humana e do mundo, ou mais largamente, a pergunta pelo sentido do ser. Como é conhecido, esta pergunta é urgente e imprescindível, para Husserl, sobretudo face à crise de sentido que ele detecta na vida da humanidade, na procura da verdade que orienta a ciência e filosofia, e que é determinante para a autocompreensão do homem; sem perguntar-se radicalmente sobre o "para onde" é orientada a existência, a que o homem realmente e em última instância aspira, não se pode compreender e realizar a vocação mais íntima, pessoal e comunitária do homem e com isso não se pode realizar o sentido. Que a existência pessoal e comunitária, histórica, tenha um sentido e uma orientação determinada, um telos, portanto, é para Husserl um pressuposto irrecusável; e não apenas pressuposto - esta é também característica fundamental dos fenômenos, evidenciada pela investigação radical e a única capaz de esclarecê-los ultimamente. De acordo com o método fenomenológico, todos os fenômenos, a fim de serem esclarecidos no seu sentido, devem ser reconduzidos à origem da sua manifestação, isto é, à subjetividade transcendental enquanto origem do sentido. A indicação importante de Husserl, portanto, é de que a teleologia esteja enraizada no ser da subjetividade transcendental e é a partir daí e por causa disso que ela pode ser encontrada também nos fenômenos e operando na história. A subjetividade transcendental é teleológica, a teleologia é a forma do seu ser (Hua XV, p. 378)² ou do processo do seu devir, já que o ser é um processo,

1 O presente texto é resultado parcial da pesquisa de pós-doutorado realizada no HusserlArchiv de Freiburg, sob a aceitação do prof. Hans-Helmuth Gander, diretor do Arquivo, a quem agradeço a possibilidade da utilização dos manuscritos inéditos de Husserl.

2 As obras de Husserl são citadas conforme a publicação original das obras completas pelo Arquivo Husserl de Louvaina, Husserliana Gesammelte Werke (Hua), com a indicação do respectivo volume e da página da citação. 
um "tornar-se", e não uma substância estática ou um conceito ou ideia formal. Em vista disso, o presente trabalho analisa a vontade como uma das dimensões do ser da subjetividade transcendental, naqueles aspectos que podem iluminar a compreensão da teleologia do ser. ${ }^{3}$ As análises de Husserl, pelas quais ele descobre a teleologia escondida, recuam para aquém e para além da vontade. Os primeiros indícios da teleologia encontram-se certamente na estrutura mais fundamental da consciência transcendental, na sua intencionalidade. Contudo, já nas sínteses passivas de tempo, onde ainda não se pode falar de intenções, como também nas aspirações instintivas e em toda a dimensão afetiva da consciência, no nível em que é afetada pela hyle e que é pressuposto em todas as atividades superiores, Husserl descobre que a vida da consciência é teleológica. Neste sentido, o presente trabalho apresenta apenas um aspecto do tema da teleologia. O tema da temporalidade, como também da intencionalidade, entrarão constantemente na reflexão, sem poderem ser devidamente aprofundados.

\footnotetext{
3 A pergunta que orienta de fundo a presente investigação é a pergunta em torno do sentido do ser. Em primeiro lugar, a pergunta em que medida este conceito filosófico, de tamanha riqueza histórica, de tamanha importância na história da reflexão humana sobre o sentido da realidade, é capaz de responder hoje às aspirações humanas ao sentido. O ponto de partida para a minha pergunta é a leitura levinasiana do problema; este filósofo conclui que o conceito de ser revela na filosofia contemporânea definitivamente a sua absoluta incapacidade de apontar o sentido para a realidade humana, intersubjetiva, por causa da sua finitude e da sua separação radical do Bem, ou do Infinito, em relação ao qual o sentido pode dar-se. A subjetividade humana, a partir da qual o sentido pode ocorrer no ser, é ligada ao Bem contra a sua persistência no ser, ou seja, num movimento contrário ao movimento de ser. A meu ver, resta ainda por investigar como se dá o ser da subjetividade responsável, ética, que responde ao apelo do Bem. Concordo com Levinas que o sentido implica abertura para o infinito, e que isto se dá na relação intersubjetiva; contudo, parece-me ainda não resolvida a relação entre o ser e o Infinito ou o Bem. Neste sentido, parece-me que Husserl pode apontar para uma alternativa a esta concepção do ser. Pode se dizer que também para Husserl o sentido implica abertura da consciência para a infinitude e a sua relação com o Bem, e que a intersubjetividade, na qual isto se realiza, é uma determinação essencial da subjetividade. A minha hipótese - que deve ser verificada e argumentada para além do presente trabalho - é que é possível com Husserl pensar o ser - a partir do ser da subjetividade que resta o único acesso ao sentido do ser - num movimento originário da abertura para $o$ Bem; que portanto Husserl, sem talvez afirmá-lo tão explicitamente como Heidegger, pensa o sentido do ser. Por isso, é importante investigar a vontade enquanto uma das dimensões fundamentais do ser da subjetividade humana, na qual a abertura para o Bem se realiza.
} 
Husserl foi conhecido - e criticado - por ter sublinhado ou privilegiado a atividade teórica da consciência. Contudo, ele não deixa de afirmar que toda a vida da subjetividade humana, por ser a vida no mundo, é sempre também e primeiramente prática ${ }^{4}$. A atividade voluntária, no mundo, é uma atividade orientada para metas, fins, e é neste sentido que ela é teleológica. A estrutura do mundo da vida, em relação ao qual em última instância a subjetividade pode ser compreendida, é uma estrutura de metas $^{5}$. Por isso, a análise dos atos da vontade na sua estrutura mais geral e fundamental, na qual eles exprimem a estrutura geral da experiência humana enquanto orientada pelas metas, oferece a compreensão de algo que é essencial na teleologia.

Nas primeiras reflexões dedicadas à ética, nas quais Husserl faz a análise dos atos de vontade, esta é tratada como uma das modalidades de atos da consciência ${ }^{6}$; paulatinamente, porém, assumirá nas obras de Husserl um papel sempre mais importante, a ponto de se tornar referida a toda a vida da consciência, e precisamente assim se mostra estreitamente relacionada à teleologia; Husserl neste sentido fala de uma intencionalidade da vontade [Willensintentionalität] e os seus comentadores do voluntarismo éticometafísico universal na fenomenologia de Husserl (MELLE, 1992, p. 304)7.

4 "A personalidade, o eu ativo, é em todas as suas atividades prática, toda objetivação é uma operação prática, e o nível último da práxis na ordem da objetivação, da constituição, é a práxis mundana: ela encerra de antemão e essencialmente, enquanto níveis nãoindependentes, o ser orientado para a realização pela experiência, valoração, aspiração, e isto é o trazer à validade e, depois, ter em validade habitualmente" (Hua XV, p. 404).

5 Cf. Hua XXIX, n. 26, p. 302-316. “O mundo existente em movimento é sempre já em formas de fim e referido aos sujeitos que põem fins (que no nosso Nós já antes tinham fins e necessidades e já os têm realizado) e também assume forma enquanto endereços a outros. De mesmo modo devemos distinguir o aspecto total, digamos 'teleológico', aspecto-defim, do mundo pré-dado, que lhe é próprio enquanto é teleológico, a partir de nós homens enquanto vivendo em fins e na interdependência social (teleológica), e a estrutura do ser deste mundo sob a abstração das intenções humanas e formas teleológicas de coisas, como estrutura do ser das pessoas e grupos e associações de pessoas enquanto correlatos" (Hua XXIX, p. 304).

6 Nas Vorlesungen über Grundfragen zur Ethik und Wertlehre de 1914, por exemplo, Husserl faz comparações e encontra analogias entre as modalidades de vontade e modalidades de julgar. Cf. Hua XXVIII, p. 102-125.

7 Neste sentido, Husserl diz: “A vida teórica é um ramo da vida prática universal”; “A razão de conhecimento [Erkenntnisvernunft] é a função da razão prática, o intelecto é servo da vontade. Porém, o servo realiza em si mesmo as funções da vontade..”(Hua VIII, p. 201-203). 
No presente trabalho não posso levar em consideração o desenvolvimento cronológico das reflexões de Husserl sobre a vontade, por isto serão entrelaçados todos os elementos da sua fenomenologia da vontade.

\section{I}

Toda a vida desperta, diz Husserl, é vida de vontade; isto significa que sempre queremos e projetamos algo, sempre temos intenções, nem sempre intenções novas, mas temos sempre já orientações de vontade, que ainda não chegaram à realização. A intenção no sentido mais largo pode ser compreendida como ser orientado para uma meta, ou, segundo Husserl, como a antecipação de uma posse - ou uma pré-pose [Vorhabe], que através do agir, da atividade, se realiza, torna-se posse [Habe].

Devemos compreender o conceito do teleológico no sentido muito largo, alargamo-lo, desde que tenhamos em vista as intenções até agora conscientes da meta enquanto metas. A palavra intenção [Vorhaben] pode significar um antecipar de uma posse [Habe] enquanto de um ente futuro, que temos antecipadamente na certeza de ser como o apresentado, que ele se tornará a partir de nós no preenchimento um ser atualmente real - realizado (Hua XXIX, p. 304).

Com isso, compreendemos uma primeira e fundamental característica da vontade: a vontade implica ter uma meta, pôr um ser no modo de antecipação. A vontade tem, por causa disso, um caráter criador. ${ }^{8}$ O que ainda é importante destacar aqui é que a intenção ou meta no sentido próprio implica uma decisão, uma "tese da vontade", uma tese prática, portanto a posição prática de um ser e de uma ação que o realiza, de um

8 "Do lado dos atos temos a dizer aqui: Em vez de o querer ser fundado sobre a crença num ser futuro, a crença antes surge de um querer. Se o querer é um querer agir, então em cada fase, na qual é efetuada a realização, (portanto o tornar-se real tem o caráter de ser agora real), este agora-real é caracterizado como originalmente criado, feito; correlativamente, o aparecer da percepção e a certeza da percepção tem o caráter de algo nascido da vontade. Enquanto tal percepção tem o caráter de uma passividade, na qual aceitamos algo que agora mesmo está aí, dedicamo-nos a um existente, a percepção que entra aqui, a da fase atual da ação, tem o caráter de uma percepção que surge da subjetividade criadora, cujo objeto é devido a um "fiat" criador. Esta é a particularidade incomparável da posição da vontade enquanto posição criadora" (Hua XXVIII, p. 107). 
caminho da realização. A tese da vontade é o próprio sentido da vontade, aquilo para o que ela tende como a sua meta e o seu fim.

[A] tese da vontade, com o conteúdo que lhe é próprio (a meta querida), funda, sem mais, a vontade que é persistentemente orientada para a meta que persiste, persiste para além do ato momentâneo que escorre. De acordo com isso, a expressão "Eu quero" significa [querer] isto ou aquilo, não meramente: eu tenho neste momento uma vivência do ato da vontade, [...], antes, num "Eu quero" há: eu me coloco ou me coloquei antes uma meta e desde então continuo - até o próximo - aquele que assim quer [der so Gewillte], aquele que tem esta "vontade" (Hua XXIX, p. 364-365).

Em relação a isso, podemos encontrar nas primeiras obras de Husserl, com as análises dos atos de vontade, distinções de vários elementos: além da decisão, pode se distinguir um momento chamado "fiat" - "seja", que seria a posição da meta querida, e a realização; neste sentido, Husserl distingue entre vontade de ação [Handlungswille] e vontade de decisão [Entschlußwille $]^{9}$ - a primeira põe um agir atual, um tornar-real da uma meta, e implica, portanto, um "fiat" realizador atual; a segunda é orientada para um agir futuro, no sentido de que um "fiat" realizador se protende numa extensão temporal e põe um ser e uma ação futura. De qualquer modo, uma outra característica definidora da vontade é que pela antecipação na intenção, os atos de vontade abrem um horizonte de temporalidade, um horizonte de futuro. Pela vontade, estamos orientados para o futuro, ou seja, a vontade põe um futuro através do seu "será" criativo, porque a vontade é a posição da realização, posição de uma operação de realizar algo futuro. Assim diz claramente Husserl: "Vontade, atividade orientada para o futuro, para o horizonte da vida futura, pelo que o caminho da realização e aquilo mesmo que realiza é antecipado" (Ms. A VI 34, 2a). ${ }^{10}$

9 Cf. BEJARANO, 2005, p. 124s. U. Melle, apoiado em vários manuscritos inéditos em que Husserl expõe reflexões sobre a estrutura da consciência, distingue entre estas três formas essencialmente distintas da posição da vontade: decisão, Fiat e vontade da realização; o Fiat é, portanto, um elemento separado tanto da decisão como da realização, embora nelas pode ele mesmo ter modalidades diferentes. Cf. MELLE, 1992, p. 292s.

10 “Já o ato do 'Eu quero', inserido no fluxo de vivências, tem um horizonte de futuro como 
Como já foi possível compreender, Husserl distingue entre um ato ou vivência singular da vontade e uma vontade duradoura: a meta ou a intenção pode perdurar para além de um ato singular. A vontade neste sentido se identifica com a meta e não é mais vista como um ato singular, ela significa a vontade disto ou daquilo como uma determinação do Eu, do seu ser; os atos singulares são como os meios para a meta ser atingida. Neste sentido, a vontade determina o sujeito como aquele que tem uma determinada meta duradora.

Interromper um fazer, ser desviado para um outro fazer, abandonar a meta, para a qual estou orientado na intenção [Vorhaben]. Mas não cancelar a pré-posse [Vorhabe], antes, depois de outro ser feito, retomar, levar adiante o anteriormente feito: a pré-posse é a pré-posse duradoura não obstante a interrupção. A pré-posse tem um início: eu me decido, dou o meu fiat, o meu sim. A pré-posse é agora vontade duradoura, mas não o ato de vontade duradouro no sentido preciso, ela é orientada para o "futuro". Um tornar-se-ser é antecipado como fim de um "caminho", de um "agir", que começa com um fiat, com um "agora eu intervenho, ponho em andamento" e em cada fase é um continuamente-manter-em-andamento, um deixar proceder voluntário até o fim, onde se interrompe com um "pronto" (Hua XXXIV, p. 355).

A partir destas palavras se compreende melhor em que sentido a vontade é orientada para o futuro: ela abre no $\mathrm{Eu}$ um ser ou modo de ser, um ser-assim que ainda não é, ela é um tender orientado para um ser futuro, que não precisa ser imediatamente alcançado, mas que está definitivamente no seu horizonte e com isso determina a subjetividade.

O que a vontade cria, portanto, não é apenas a realização da meta, mas ela forma o próprio sujeito, o Eu, que a partir de cada ato, mas também a partir da decisão por algo, a partir da vontade, é determinado por ela,

o de sua validade [Fortgeltung]. Com o momento do 'Eu quero', 'Eu decido', sou o de agora adiante decidido. Portanto, no modo de ser do Eu que realiza o ato, respectivamente neste ato, na sua 'intenção' ou 'sentido', nesta antecipação, está pré-projetada [Vorentwerfen] precisamente esta temporalização, este campo temporal. O mesmo vale para o campo aberto da ação a ser futuramente realizada por mim, que teria 'realmente realizado' a minha meta de antemão 'pensada' no querer. [...] Enquanto dirigido para a minha meta, estou dirigido para algo futuro, primeiramente para o que deve ser realizado por mim, no querer que inicia agora (como me decidindo)" (Hua XXIX, p. 367-368). 
mesmo que a vontade e a sua meta futuramente mudem. Pelos seus atos, pelas decisões de vontade, o Eu se forma ou constitui como pessoa, única e irrepetível; isto será muito importante para o desenvolvimento do tema. Husserl repetidamente sublinha este aspecto. Voltaremos a isto mais adiante.

Um outro aspecto a ser sublinhado no âmbito da vontade é a sua relação com a liberdade. A vontade, com o momento da decisão, da tomada de posição, pressupõe a liberdade, mas não se confunde com ela. Ela se funda na espontaneidade própria de todos os atos da consciência, nos quais o Eu se dirige ativamente, intencionalmente, para o seu objeto; a esta espontaneidade, ato no sentido forte, Husserl chama "Reino da liberdade". A vontade, neste sentido, é uma modalidade dos atos espontâneos; Husserl diz, portanto, que querer só é possível no campo da espontaneidade ${ }^{11}$, mas, como todo ato do $\mathrm{Eu}$, e como um ato do âmbito prático, insere-se no mundo ou sistema das suas possibilidades práticas, de um "eu-posso" determinado pelo corpo (kinestesias), e pelo mundo ambiente. A meta se apresenta sempre como uma das possibilidades práticas a serem realizadas no mundo ${ }^{12}$. A vontade, precisamente pela sua relação com a liberdade, se revela como uma dimensão essencial para a realização da vocação do homem a ser livre e, por isso, absolutamente responsável.

Ora, diz Husserl, na nossa vida normal temos sempre já metas e intenções, muitas delas assumidas mais ou menos ingenuamente, ou passivamente a partir da tradição, ou metas que perduram numa habitualidade

11 "Temos que distinguir, portanto, espontaneidade (reino da liberdade) e vontade. Em vez da espontaneidade falamos também do ato no sentido preciso, tomada de posição (...). Entre os tipos de atos, um é a vontade" (Ms. M III 3 III 1 I, p. 105). Em Analysen zur passiven Synthesis, Husserl brevemente menciona a espontaneidade do desejo, das emoções, do valorar e de todo o comportar-se prático, assim como, obviamente, espontaneidade do juízo (Hua XI, p. 361).

12 "Estas possibilidades práticas são possíveis metas de ação, possibilidades do Eu-posso, possíveis-imagináveis fins dos processos do conseguir voluntário, do agir. Eu poderia isto e aquilo, eu quero isto, "tenho em mente" uma ação, um fim (telos), como fim de uma ação, é pré-presentificado [vorvergegenwärtigt], antecipado, eu digo sim. Temos, porém, que considerar bem, o que significa este ter em mente: não uma mera apresentação [Vorstellung] e em relação a isto um fiat como vontade. O que tenho em mente já o tenho como uma possibilidade prática. O que é consciente como válido [Gekonntes] é em si já um modo da vontade, modificação intencional de um modo originário enquanto fazer e ato" (Hua XXXIV, p. 356). 
pessoal sem serem refletidas, e elas fundam tarefas também não refletidas ou esclarecidas. As metas são assim muitas vezes conscientes como préideias e não são intenções no sentido próprio e forte, não são decididas a partir da reflexão. A nossa vontade, como todos os atos da consciência é, pois, motivada, ou seja, despertada por alguma motivação, que é o tipo da causalidade no âmbito espiritual ${ }^{13}$. Husserl distingue entre motivação passiva e ativa ${ }^{14}$, ou ainda entre irracional e racional. Na motivação passiva, o Eu é movido pelos impulsos e instintos e estes certamente são como o solo, a primeira modalidade do tender da subjetividade, sobre o qual se constituem as decisões da vontade, orientação ativa para o fim. A vontade é neste sentido uma modalidade superior de consciência já fundada sobre outras modalidades, precisamente sobre a apresentação dóxica de um ente (por exemplo, na percepção) e a valoração deste ou de um acontecer futuro, enquanto praticamente possível. O querer se orienta sempre para um suposto valor, e o valor é o motivo do querer (MELLE, 1992, p. 290). "Todo o agir, todo tender [Abzwecken], é referido a valores" (Ms. A V 21, 14b), diz Husserl, e ainda:

[...] o que é ambicionado como meta ou meio, neste sentido considerado valoroso, também todo o útil enquanto tal, é um valor, um bem

13 "A causalidade espiritual chamamos motivação, isto foi uma expressão geral para o modo, como os fatos espirituais aparecem "na base" de outros fatos ou "porque" estes apareceram. Precisamente, este nexo entre Por que e Porque [Warum und Weil] é um nexo que cai absolutamente na espiritualidade, ele mesmo espiritual. A causalidade espiritual ou a motivação é a partir daí algo totalmente compreensível e está em cada passo sob as leis de essência, de acordo com as quais pode ser tornada compreensível, dito por princípio, de ponta a ponta, toda a gênese espiritual" (Hua XXXVII, p. 109).

14 "Primeiramente posso distinguir motivação passiva e motivação ativa, primeira acontece involuntariamente, sem qualquer atividade de tomada de posição, a segunda é ativa. A primeira é psíquica, sub-pessoal, ela cria o subsolo do Eu pessoal, opera na construção de todas as apercepções, e com isso é fundida e montada a constituição do mundo-circundante enquanto força criativa [Gestaltungskraft], que deixa aparecer objetos sem a participação ativa do Eu e os objetos, que já mantiveram significação ativa sem a participação do Eu (do intellectus agens). Por outro lado, cada atividade tem a sua própria operação de um nível superior, ela cria um mundo de razão no sentido mais alto. [...] Podemos também dizer agora: A motivação passiva é o solo [Mutterboden] da razão e como tal tem a receptividade [Empfänglichkeit] para o intellectus agens e para o sujeito da razão ativa no seu reinar da razão" (Hua XXXVII, p. 331-332). 
[Gutwert]. Bens são valores. Obviamente não são valorizados apenas de modo emotivo [gefühlsmäßig], mas, na base deste considerar valoroso são também pensados como almejados ou como meta e meio (Hua XXXVII, p. 315).

Com isto, a análise da vontade se inclina essencialmente para ética. $\mathrm{O}$ ato de pôr o valor é o fundamento da vontade, e este, por sua vez, segundo Husserl, é um ato emocional, ou seja, os valores têm coloração emotiva, eles são constituídos mediante sentimento (Hua XXXVII, p. 326-327), mas não somente - eles são também pensados enquanto meta, nas palavras de Husserl. Isto será muito importante para a compreensão da teleologia. No interior da posição de valores ainda são possíveis diferenciações: a preferência por um valor pode precisamente dar-se impulsivamente, passivamente, como foi dito, mas também conscientemente, sem, contudo, ser justificada ${ }^{15}$; pode, por outro lado, ser refletida e pensada, ter a forma de decisão pessoal, própria, capaz de ser justificada. Decidir a partir da evidência significa ter em vista o próprio valor (BEJARANO, 2005, p. 273 274). Certamente, a descoberta e a realização do sentido da vida subjetiva e da humanidade, a descoberta da teleologia, do "para onde" nós realmente queremos, se dá pela autorreflexão. Voltaremos a isto mais adiante. Há uma distinção a ser feita também entre metas que são apenas intermediárias, mais ou menos passageiras, e a meta que perdura enquanto uma meta final, que pode ser realizada através de atos intermediários que têm as suas metas intermediárias. ${ }^{16} \mathrm{Na}$ decisão por esta meta há já um caminho indicado, os

15 "Já temos claro, que também as preferências podem ser corretas e incorretas, obscuras e compreensíveis, que o melhor pretendido pode ser um pior e o pior presumido, na verdade, um melhor. Além disso, devemos também tomar em consideração que a preferência [Bevorzugung] pode ser inautêntica [uneigentliche], um cego ser arrastado impulsivamente para a realização de uma possibilidade, sem que se possa falar de um ato de vontade próprio e uma decisão própria de escolha, nas quais o Eu a partir de si tome posição numa motivação de ato e se decida para o melhor. As emoções passivas têm as suas insistências afectivas, entram em concorrência, e uma avança mesmo como a mais insistente [...]. $\mathrm{O}$ sujeito que sente, que cede à emoção passiva que afeta mais fortemente, não realiza com isto nenhuma própria preferência, nenhum ato livre da tomada de posição preferencial, na qual uma emoção evidencia o seu substrato como o melhor" (Hua XXXVII, p. 232).

16 "Entre as partes do ato distinguem-se as que estão em função de servir [dienender Funktion] daqueles que exercem a ação dominante [herrschende Aktion], isto é, nas quais 
atos que a realizam e que são projetados pela meta esboçam um horizonte do futuro, que determina o $\mathrm{Eu}$, o fazem ser este $\mathrm{Eu}$, decidido de tal e tal modo. A meta como interesse do Eu diz precisamente aquilo junto a que o Eu está, ou a que ele aspira como Eu, para onde o seu ser se orienta. A multiplicidade de atos, de interesses que os movem, e que formam o fluir constante da vida da consciência, deve de algum modo confluir para uma unidade, para que o Eu possa permanecer, segundo uma lei essencial que rege a vida da consciência em todos os seus níveis - e esta unidade se dá precisamente pela vontade, pela posição de fins com as quais o Eu decide a sua vida. Pela escolha de metas duradouras, para as quais se orienta através de muitos atos, através de escolhas intermediárias e preferências em caso de contradições e conflitos, o Eu realiza a unificação da sua vida intencional ${ }^{17}$. Além de ter uma dimensão criativa, a vontade é decisiva para a constituição da individualidade do $\mathrm{Eu}$, e com isso ela é referida não apenas ao futuro, ao novo, mas também ao passado, à conservação

está aquilo que o sujeito do ato e o ato unido, por assim dizer, quer alcançar. [...] Através da intenção que serve passa, porém, a função dominante, que rege o processo, nomeadamente a vontade que age, como um querer que no fazer realizador e também através dele está orientado para a forma final. [...] Como ato do interesse no sentido exato devemos agora tomar tal ato, que o Eu não tem apenas em geral no olhar da consciência, do qual ele está de algum modo, de passagem, consciente, mas para o qual ele está dirigido num sentido forte, ao qual ele mira, para o qual tende, onde quer chegar. [...] Devemos também distinguir um tema momentaneamente atual, e no interior deste diferenças de outros temas como aquele, para onde vai o olhar final, contra aqueles que são 'meios' (premissas) para isto - e o reino dos temas habituais, que permanecem na 'pose espiritual' como interesses permanentes e, novamente atualizados, que enquanto temas já feitos têm contudo o caráter do já conseguido, mas por causa disto continuam sendo interesses, mesmo no modo de posse uma vez atualmente obtida. [...] Através da multiplicidade dos atos entrelaçados, dos quais cada um 'tem' o seu interesse (aqui compreendido onticamente, como a meta do conhecimento), passa a unidade de 'um' interesse, que estendendo-se une todos os interesses particulares" (Hua VIII, p. 101-103).

17 "Eu, realizando múltiplos atos, sou a partir disso Eu numa multiplicidade aberta-sem-fim de validades. Sempre de novo entram validades em contradição com validade, aparecem modalizações. O que significa, que eu não posso ser em contradição comigo mesmo? Eu posso apenas ser, se todo o meu querer é a unidade de um querer, que é precisamente "unânime". Querer muitas coisas atualmente é ao mesmo tempo querer um querer. $\mathrm{Na}$ sequência, o novo deve convir, de outro modo aparece modalização. Na habitualidade sou também o Eu que tem todas as posses numa. Na unanimidade está a possibilidade do devir ao mesmo tempo atual; mas aí despontam contradições. Eu quero 'ser' o mesmo, aquele que sou, ser Eu unido na unidade de um mundo, na unidade da vida da vontade etc." (Hua XXXIV, p. 360, nota 32). 
da identidade do Eu pela persistência das metas e pela fidelidade às metas assumidas, e com isso é relacionada com a memória; a história pessoal de tomadas de posição é importante para compreender a individualidade do $\mathrm{Eu}$, e para a constituição da sua pessoalidade. Por isso, Husserl fala da tendência à conservação, a preservação do ser, que acontece pela constituição de habitualidades nas decisões. O Eu não é um polo vazio, mas uma pessoa concreta, determinada na sua vida de Eu. Se as decisões e tomadas de posição do Eu, nas quais o Eu vive, fossem sempre diferentes, fragmentadas, não haveria identidade; a identidade pessoal se forma pelas tomadas de posição que duram, que se sedimentam e se tornam convicções habituais. "Ser como Eu, como pessoa, é, como vemos, ser persistindo num modo próprio, até pessoal, e ser o mesmo nas mudanças" (Hua XXIX, 365). A unificação do Eu como pessoa é estreitamente ligada ao tema da teleologia. Ela é um aspecto importante da aspiração de fundo que Husserl encontra na vida da vontade, e sobre a qual são fundados todos os interesses e metas particulares. Assim como no campo do conhecimento, a aspiração de fundo é a de chegar à coisa mesma, na qual todos os aspectos da coisa, do objeto, são unificados e as contradições superadas na evidência do ser da coisa, assim também do ponto da vista da vida da vontade, que no fundo rege também a vontade do conhecimento, há um aspirar à unificação não só do mundo, mas do próprio Eu que por meio de todos os atos determina a si mesmo e não pode não ser sempre o mesmo. Assim como no campo do conhecimento, a verdade deve superar as contradições, o Eu, pressuposto na atividade de conhecer, também não pode ser em contradição consigo mesmo, nas suas múltiplas metas e tarefas. Aunidade do mundo é na verdade fundada na unidade do Eu, sujeito de todos os atos pelos quais o mundo se constitui na sua unidade. A aspiração do Eu ao sempre novo, ao que vem, que é como um impulso de passar de uma meta a outra, infinitamente, que entrelaça as múltiplas tendências particulares, é ao mesmo tempo um tender ao fim que realize todas as aspirações e metas, que realize o Eu e lhe confira a unidade definitiva e que possa manter-se definitivamente. A vontade, no sentido mais originário, implica para além de todas as metas mais ou menos duradouras, particulares, este aspirar que unifica a vida 
inteira, total, do Eu: "Aspiração universal à concordância. Vontade de ato dirigida à concordância [Einigkeit]” (Hua XXXV, p. 430, nota 1).

Em última instância a vida do Eu atravessa uma aspiração de chegar a uma unidade e unanimidade na multiplicidade de suas convicções, de tal modo que o Eu se torne um Eu que permanece fiel a si mesmo ou pode permanecer fiel, desde que não esteja disposto a mudar as suas conviç̧ões... (Hua IX, p. 214).

Neste sentido, ultimamente, para Husserl a vontade não é apenas um entre muitos modos de atividades conscientes, "mas uma forma especial e mais alta da atividade que, sob certas condições essenciais, que estão nas objetivações e no sentir pressupostos, pode entrar em cena por toda a parte" (Hua XXXI, p. 10). Neste sentido preciso, a vontade é uma determinação do Eu pessoal, ela explica em si o ser do Eu: as decisões e convicções do $\mathrm{Eu}$ determinam o seu ser. A unidade da vontade, na qual estão incluídas todas as operações intencionais da pessoa, é por isso a unidade do ser da subjetividade, da pessoa.

Todas as minhas intenções, intenções neste sentido primeiro [como "ter atualmente em vista, obter, obtendo ter uma posse"], no seu movimento formam uma unidade, não uma ao lado da outra, elas são todas raios da minha vontade unitária, do meu ser unitário. Eu, um e o mesmo $\mathrm{Eu}$, sou nesta vontade, na multiplicidade de uma única orientação da vontade, o Eu uno da vontade. [...] Todas as vontades positivas singulares têm a sua unidade na unanimidade [Einstimmigkeit], na qual eu sou sempre o mesmo $\mathrm{Eu}$, o que permanece na pluralidade das vontades que realizo e que mantenho na realização (Hua VI, p. 470). ${ }^{18}$

Com isto, chegamos a um momento importante para o desenvolvimento do tema. De fato, a partir desta análise mais geral da

18 “[...] pelo que, porém, a realização não tem a atualidade no sentido de um ato como uma vivência particular. Esta é a realização no segundo sentido. A vontade, ter uma vontade uma, ser nesta vontade, não é o ato da vontade momentâneo, também cada ato é em si já o empenho ou a retomada de uma vontade que permanece, de um aspecto do Eu que permanece" (Hua VI, p. 470). Sobre o tema da vontade e sua relação com a unificação e individualidade do Eu e preservação do Eu verdadeiro. Cf. também NOOR, 1991, p. 137ss. 
vontade como orientação para uma meta e da aspiração à unificação da vida, pode colocar-se a pergunta sobre qual é a meta derradeira ou mais autêntica da vida da pessoa, que pode revelar o sentido ou telos de toda a aspiração da vida da consciência e da humanidade, e desencobrir a "teleologia escondida" da humanidade. Husserl se pergunta explicitamente sobre uma meta final que faz a unidade do Eu e da sua vida, num dos manuscritos ainda não publicados em que analisa a continuidade e a unidade do ato intencional através de vários períodos de interrupção:

A unidade última de todos os atos num Eu como o seu realizador. Em que modo atravessa a „vida“ de um Eu, em geral de um Eu humano - uma intenção universal de nível superior? Problemas novos: como se caracteriza a unidade de uma vida do Eu - através de todos os períodos despertos? $\mathrm{E}$ a unidade desta vida ordenada àquela de todos os homens, através de todas as vidas individuais (Ms. B III 9, 25a).

No manuscrito citado, a pergunta de Husserl permanece sem resposta, contudo, penso que seja possível concluir algo sobre isto a partir de outros escritos.

Husserl desenvolveu em várias obras e, portanto, relacionada a diferentes aspectos da fenomenologia, a diferença entre a vida ingênua, natural e a vida orientada para a clareza e evidência. Assim, na vida científica, que corresponde à aspiração à verdade, o conhecimento ultimamente fundado das coisas, a ciência radical das origens capaz de fornecer justificação para todas as outras ciências, é a filosofia. Ela responde às mais altas necessidades teóricas do homem ${ }^{19}$. Husserl a chama também de "omnisciência" [Allwissenheit], e certamente neste sentido ela não é realizável pelo filósofo singular, mas pela comunidade de filósofos,

\footnotetext{
19 Segundo Husserl, a filosofia é uma tarefa, uma meta formulada - descoberta interiormente e conscientemente posta - pelos filósofos e realizando-se através deles na história. A partir da sua fundação originária entre os gregos e em toda a sua história, ela tem "uma forma [Form] comum, que exposta poderia ser assim expressada: 'Ciência do universo dos entes enquanto ciência para todo o 'racional', para todo aquele que pensa na episteme pura, que conduz à criação do conhecimento definitivo do mundo"” (Hua XXIX, p. 405).
} 
num progresso infinito; ela é uma ideia no infinito, que motiva a pesquisa pessoal do filósofo como a sua meta derradeira que orienta toda a sua vida, como o telos. Husserl se exprime assim num complemento à obra Erste Philosophie, intitulado "Meditação sobre a ideia de uma vida individual e comunitária na absoluta auto-responsabilidade": "filosofia, unidade

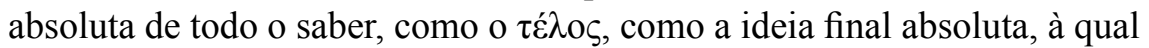
aspirando todas as realizações são orientadas" (Hua, VIII, p. 196). O saber radical, justificado, é em última instância para Husserl questão de liberdade e responsabilidade do homem; por sua essência - por ser capaz de conhecer e por ser livre - e em última instância pela sua vocação interior, por causa da teleologia, como veremos - o homem é capaz de ser responsável, nisto está a sua dignidade, como deixa compreender a seguinte expressão: “A mais alta dignidade da autenticidade, da capacidade da responsabilidade que alcança radicalidade" (Hua XVII, p. 283) ${ }^{20}$. Por ser capaz de responsabilidade, o homem é como que chamado à responsabilidade, a se justificar radicalmente na sua vida no mundo e na comunidade. É esta ideia da filosofia e da sua tarefa que enquanto telos, polo unitário, une interiormente filósofos numa comunidade e orienta a história da filosofia ${ }^{21}$.

Com isso, porém, tocamos um outro aspecto da pergunta sobre a meta da vida humana, nomeadamente a sua relação com a vontade enquanto decisão e posição de metas. Ao falar, no escrito Philosophie als strenge Wissenschaft, da filosofia como tendo desde o seu início a pretensão de ser uma ciência rigorosa que satisfaz a mais alta necessidade teórica da humanidade, Husserl adiciona também que ela desde o início pretendeu possibilitar uma vida ético-religiosa orientada pela pura razão

20 Guilhermo Hoyos Vásquez, na bela obra Intentionalität als Verantwortlichkeit, mostra a relação entre a aspiração à verdade que orienta originariamente já a intencionalidade, e a capacidade de responsabilidade do homem, ligando-a sobretudo com a teleologia da história. "O significado desta compreensão da teleologia, sobre a qual Husserl indaga até os níveis mais profundos da constituição na síntese passiva, é a apresentação da referência originária da verdade na capacidade originária da subjetividade, que tanto na gênese passiva como na ativa se comprova na sua capacidade de responsabilidade universal e absoluta" (VÁSQUEZ, 1976, p. 11).

21 "O telos existe a partir do filósofo fundador originário - ele existe enquanto compreendido, enquanto assumido apoditicamente pelos outros e sempre de novo outros - ele faz a unidade interior, especial, da comunidade total [Allgemeinschaft] de todos os filósofos na unidade da história. Ele é identicamente o mesmo, a mesma idéia-tarefa em todos eles, o pólo idêntico

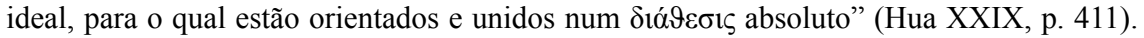


(Hua XXV, p. 3). O saber filosófico teórico pode, pois, segundo Husserl, orientar também a vida prática do homem para a clareza e assim para a liberdade. Husserl, assim também no campo da vontade, distingue entre a vida ingênua da vontade e uma vida certa de normas, conscienciosa. Esta não significa apenas realizar atos com consciência da sua verdade, da autenticidade ou veracidade da intenção; também na vida ingênua podem ser realizados tais atos, uma vez que também a evidência pode ter diferentes níveis. Para a vida regulada radicalmente pela razão, não é suficiente a reflexão sobre as próprias metas e caminhos para as realizar, que o homem faz espontaneamente, talvez esporadicamente, motivado pela vontade de ser bem sucedido - uma das características do modo de ser humano, segundo Husserl - frente a insucessos na realização de metas pretendidas, a fim de esclarecer o que foi obscuro numa determinada meta e na ação ${ }^{22}$. Isto é ainda um modo ingênuo de viver que não corresponde à aspiração humana fundamental; na assunção não radicalmente esclarecida das metas, o homem permanece encoberto para si mesmo.

Antes, a vida da vontade conscienciosa significa viver "na vontade de pensar, valorizar e querer ajuizadamente, e de acordo com isso ter convicções originárias, aquisições originárias a partir da razão verdadeira" (Hua XXXVII, p. 248). A vontade ou a decisão da verdade e autenticidade, a vontade de viver orientado pela razão é, portanto, fundamental.

22 “O Homem é sempre já sujeito de interesses práticos e tem, sobretudo quando funda interesses novos (se coloca novas metas, que tornando-se habituais são a partir de agora próprias a ele como seus interesses), atrás de si sempre já uma tradição infinita, e a partir dela sempre já um mundo circundante com um aspecto tradicional, mas pode frequentemente, na realização dos interesses que a cada vez se apresentam, abandonarse ao método habitual desta realização. A atividade originariamente livre, mais ou menos completa na formação das intenções [Vorhaben] e suas realizações, muda-se numa "cega" passividade, nas situações semelhantes deve deixar-se levar a agir quase instintivamente. Mas isto leva frequentemente à falência das intenções, em geral o deixar-se andar assim é novamente a "razão" [Vernunft]. O falimento enquanto a possibilidade prevista motiva a livre intervenção previdente, nomeadamente uma reflexão livre, uma orientação da vontade [Willungsrichtung] habitual de trazer à evidência as intenções, esclarecendo-as e, obviamente, a sua referência à situação frequentemente apercebida somente vagamente, que portanto deve ser esclarecida junto. Viver como Eu maduro, desperto no seu mundocircundante respectivo, não é apenas viver de qualquer modo, mas querer viver com bom êxito [gelingend]. Ao este querer-viver e poder-viver serve como elemento fundamental o conhecimento" (Hua XXIX, p. 383-384). 
Na vida da vontade, tanto ativa quanto passiva, as intencionalidades da esfera de valorações e de conhecimento se entrelaçam ${ }^{23}$, e a vontade humana é a vontade racional, orientada para as metas que reconhece como devidas. Deste modo, apenas a vida científica é aquela que se caracteriza propriamente pela ausência de conhecimentos ingênuos e a vontade consequente de conhecimento normatizado.

Contudo, Husserl insere aqui um alargamento importante: o conhecimento científico é apenas um dos aspectos ou interesses do cientista; já a própria valorização da verdade científica, embora possa ser evidente e verdadeira, pode, contudo, ser ingênua, no sentido de não ser interrogada a normatividade deste valorizar. O cientista é, além disso, homem, cuja vida tem muitas dimensões que têm pouco a ver com os interesses científicos, e em muitas esferas extracientíficas ele pode viver ingenuamente. Pertence, porém, à essência do homem a "característica maravilhosa" de poder haver uma autonormatização, uma orientação de toda a vida para a justiça que ultrapassa todos os interesses particulares e especiais, como por exemplo o da profissão. E, além disso, na vida a partir da razão não se trata apenas da extensão da aplicação da razão para a totalidade da vida, mas também da intensidade. O cientista, por exemplo, não aspira apenas à verdade, mas a uma teoria sistêmica universal e ao sistema melhor. O melhor é o inimigo do bom, diz Husserl, e é o melhor aquilo que deve ser procurado pela razão, porque ele absorve em si todos os bens menores e as revela como praticamente menos valorosos. Se consideramos agora o homem na sua "profissão universal", então a profissão do homem "não deve ser nenhuma outra do que a de ser homem, o homem mais pleno, mais autêntico, o mais verdadeiro" (Hua XXXVII, p. 251-252). Esta é, em última instância, a meta da vida humana: tornar-se o melhor homem possível, alcançar na própria pessoa, na própria individualidade, a maior perfeição possível ${ }^{24}$. O

23 "Toda a vida se realiza num sentido mais largo na aspiração e é neste aspecto prática, ela se realiza como a vida de impulsos passivamente ou como a vida própria da vontade ativamente nos atos do Eu, pelo que porém, de ambos os lados e nas misturas constantes as intencionalidades da esfera do valorar e de conhecimento são fundantes" (Hua XXXVII, p. 248).

24 "Cada um de nós diz: Eu - eu quero viver a minha vida inteira, a partir de agora, em todos os seus atos e com todo o seu conteúdo de vivência, de tal modo, que ela seja a minha melhor possível vida; o meu melhor possível, isto significa o melhor possível que eu posso. 
homem pode reconhecer em si mesmo uma distinção entre dois modos de ser e de viver humano: o seu viver natural, o que ele atualmente é, e o que procura no seu agir e no seu desenvolver-se, a ideia do seu Eu verdadeiro, daquilo que deveria ser, mas ainda não é. A ideia do homem verdadeiro e autêntico, porém, não é para Husserl, sobretudo nos seus textos tardios, uma ideia geral, ela é em cada pessoa individual e implica que o homem pode desenvolver-se apenas de tal modo, "que ele na ação por iniciativa própria [selbsttätiger] enquanto Eu livre procura para si a sua ideia, até a descobrir e apreender, e que a partir de então transforma a si mesmo no sentido deste seu Eu verdadeiro, quer formar novamente a si mesmo de acordo com ele" (Hua XXXVII, p. 240). A isto corresponde a vontade, segundo Husserl, de regular claramente a própria vida individual, na sua infinitude, de acordo com esta vida como o dever absoluto ${ }^{25}$.

Ora, em que consiste esta perfeição e autenticidade e como pode o Eu chegar a sua compreensão?

A reflexão sobre o ser da pessoa, que alcança a profundidade a partir da qual as convicções e decisões mais próprias e autênticas podem ser realizadas, a partir da qual as metas autênticas podem ser desencobertas e postas conscientemente, é feita, segundo Husserl, somente pela filosofia, precisamente pela autorreflexão fenomenológica do filósofo. Apenas pela mudança radical da atitude ingênua para a realização da epoché de todos os interesses e metas espontaneamente postas e seguidas, é descoberta a subjetividade operante em todos os atos, o sujeito da vontade, e com isso o ser do Eu pessoal, autêntico. ${ }^{26} \mathrm{O}$ filósofo pode refletir, assim, radicalmente apenas sobre o seu próprio ser e a partir de si mesmo alcançar

Esta é para mim a vida devida e absolutamente devida. O dever é o correlato do querer, e isto de um querer racional, o que é devido é a verdade da vontade" (Hua XXXVII, p. 252). 25 A partir desta ideia absolutamente pessoal e individual do Eu que eu devo tornar-me, há contudo um caminho para a comunidade e universalidade, como veremos adiante.

26 "Porém, a nossa inteira autêntica, própria vida do Eu, na qual estas metas estão fundadas e conservadas na validade duradoura através de múltiplas mudanças [...] - esta vida permanece completamente escondida para aquele que é ingenuamente dedicado aos seus interesses. Permanece assim para nós, até que aprendamos a realizar mudança total da atitude, a total virada temática para a subjetividade operante enquanto tal. Apenas nela vemos aquilo que antes, na ingenuidade cotidiana da vida, nunca foi visto, o que faz o nosso ser-Eu pessoal autêntico, próprio, enquanto o ser da vida que funda o ser duradouro em atos pessoais e que intenciona pessoalmente" (Hua XXIX, p. 370-371). 
a universalidade, e isto é ao mesmo tempo, para Husserl, uma exigência ética de responsabilidade em todas as dimensões da vida. Num belo trecho de um complemento a Erste Philosophie, Husserl exprime isto:

Se agora nos recordamos do que no início foi dito sobre a universalidade, com a qual a filosofia abraça todos os tipos de operações da subjetividade, então é claro que esta idéia da autoresponsabilidade absoluta - uma responsabilidade pela verdade plena e absoluta - à qual um sujeito filosofante é submetido, deve ter um significado mais profundo. Se consideramos que todo o fazer, querer e sentir humano pode tornar-se objeto de ciências, nas quais se torna tema teórico, e se consideramos adiante que este conhecimento teórico pode imediatamente experimentar uma mudança normativa, segundo a qual se torna regra para uma práxis etc., então compreendemos que a filosofia - enquanto ciência universal, chamada a ser a fonte originária, da qual todas as ciências tiram a sua justificação última compreendemos que uma tal filosofia não pode ser nenhum passatempo da humanidade, que uma vida filosófica deve ser compreendida como uma vida totalmente a partir da auto-responsabilidade: o sujeito individual pessoal, enquanto sujeito da vida pessoal, quer em toda a sua vida, em toda a sua práxis decidir-se livremente verdadeiramente, isto é de tal modo, que em cada tempo pode responder pela razão da sua decisão diante de si mesmo (Hua VIII, p. 197).

Husserl explica o telos, ou a meta autêntica que orienta primeiramente a vida subjetiva, como a aspiração ao ser verdadeiro e autêntico, como ideia de uma perfeição absoluta infinita, da existência própria verdadeira e autêntica ${ }^{27}$. Esta ideia, como já foi dito, é a ideia do próprio Eu pessoal e individual, da sua verdade e autenticidade, que cada pessoa pode descobrir apenas em profundidade de si mesma como o ideal para o qual aspira mais intimamente, como brotando do núcleo mais íntimo

27 "Ideia de uma existência [Dasein], a mais perfeita no progresso infinito, que supera as contradições necessárias da existência [Dasein] e através disto eleva-se no acordo consigo mesmo ao ser verdadeiro, uma existência [Dasein] que se renova para a verdade ("renovação", homem novo 1. Na vontade desperta da autenticidade, 2. Na vontade de querer viver segundo a idéia do progresso, de querer ser como homem novo na eterna renovação, repetindo-se sempre de novo)" (Hua XV, p. 379). 
da pessoa, isto é, do seu Eu mais verdadeiro que é neste sentido o mais pessoal. A subjetividade transcendental, que pela reflexão pode descobrir em si mesma esta aspiração como o seu telos, pode também decidir-se livremente e conscientemente para a vida que realiza esta ideia. A decisão para este valor, isto é, para a realização da ideia do meu Eu mais pessoal, é aquele projeto ético individual que é o fundamento mais profundo da individualidade e identidade pessoal do Eu (MELLE, 1991, p. 131), e ao mesmo tempo o caminho para a realização da sua unidade mais profunda. Esta é uma unidade teleológica, diz Husserl (Hua XXXV, p. 430, nota 1), o Eu a descobre como a sua vocação mais profunda e autêntica, aquela a que é chamado pessoalmente e irredutivelmente.

O caminho para a sua descoberta e realização é ainda a crítica radical, apodítica, que deve ser uma autocrítica, ou seja, a crítica radical do Eu pessoal ${ }^{28}$. Nela, em última instância, se unifica a vida do Eu num sentido novo: unificam-se as dimensões teórica e prática da razão, da verdade, da vida ${ }^{29}$. Ela é ao mesmo tempo orientação da vontade para a verdade definitiva e, com isso, a decisão para a formação de si mesmo de acordo com esta verdade, o que apenas torna possível aquela ideia de mim

28 "A crítica apodítica é o meio da produção da verdade enquanto definitividade. A verdade apodítica é apenas uma outra palavra para a definitividade. Isto não diz outro que: a crítica é o meio de formar a mim mesmo de única forma possível, na qual posso permanecer fiel a mim mesmo, na qual não posso colocar-me e chegar numa situação de tornar-me infiel a mim mesmo, o que é claramente um ideal. [...] O Eu conscientemente orientado para a verdade universal e correlativamente orientado para si mesmo, para a auto-formação do Eu que pode permanecer sempre fiel a si mesmo, pode sempre ser de acordo consigo mesmo. A verdade universal, porém, não é um feixe de verdades sem conexão, teóricas e práticas. Assim teríamos com maior razão um Eu multicolorido sem unidade. Chegamos, portanto, a uma unidade teleológica, como o é uma ciência universal e uma práxis universal que está sob uma meta superior. [...] Apenas a orientação da vontade da minha vida à verdade e autenticidade universal me garante uma vida que posso viver como unanimemente satisfatória, e torna possível para mim ser ou tornar-me um Eu que é uno consigo mesmo, permanece fiel a si mesmo, pode ser idêntico consigo mesmo enquanto pessoa, unidade de uma personalidade nunca rompida" (Hua XXXV, p. 430-431, nota 1).

29 Noor fala da ideia da concordância de validade nos campos teórico, axiológico e prático, como a própria manifestação da razão, que torna possível a afirmação da pessoa, da comunidade; a vontade desta concordância é a vontade da razão, a ela está ligada a ideia da autonomia da pessoa, no pensamento de Husserl. Cf. NOOR, 1991, p. 138-139. 
mesmo à qual posso permanecer fiel definitivamente. Esta autorreflexão, autocrítica e decisão universais mais altas são éticas; são uma autoformação que opera a partir das fontes da verdade e autenticidade e forma uma vida nova e verdadeira (Hua VIII, p. 155). Husserl chama esta autoconsideração

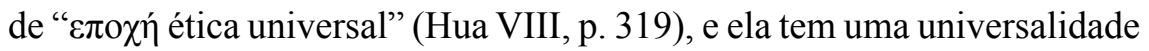
totalmente diferente da epoché fenomenológica:

Ela diz respeito a todas e cada uma das validades, que estavam em jogo nos atos pessoais da minha vida até agora. [...] Ela diz respeito originariamente a todos os atos que se referem ao dever absoluto e ao que neste respeito é relevante no campo prático universal (Hua VIII, p. 319).

Com este novo tipo da epoché, o fenomenólogo ganha uma nova visão sobre toda a sua vida, que não é apenas teórica, mas prática, ética. Trata-se, portanto, na epoché ou decisão ética, de reflexão e decisão sob o ponto de vista de valores absolutos e do dever absoluto, trata-se de confrontar-se com o valor absoluto que é absolutamente pessoal, como vimos, de confrontar-se com a infinitude da sua exigência, e de decidir a vida a partir dela. Husserl distingue, pois, entre os valores relativos e os absolutos. Sobre isto muito poderia ser dito, mas para os fins deste trabalho posso apenas esclarecer que o valor ou dever absoluto é para Husserl aquele ao qual a subjetividade, na reflexão universal a partir de si mesma, não pode renunciar sem renunciar com isto a si mesma; são aqueles valores que neste sentido absolutamente devem ser metas da vontade, pessoais e ao mesmo tempo compreendidas como metas válidas para todos. O seu ser é ideal que surge necessariamente a partir da vontade, como uma exigência da vontade que o Eu descobre em si mesmo como a sua obrigação pessoal ${ }^{30}$. Num outro manuscrito Husserl esclarece, como já foi mencionado, que

30 “Também ideais são seres, porém a partir do fato de eu decidir por eles, como os meus ideais, que não são um belo que eu gozo, mas um belo que eu na infinitude da sua idéia devo querer, ou: eles são através do fato de eu os experimentar como os que correspondem a mim, que me são exigidos como um dever absoluto. Aqui surge um ser ideal a partir da vontade, não a partir de uma arbitrariedade, mas de um Eu pessoal como uma exigência absoluta da vontade, sem a qual ele não pode ser, à qual ele não pode renunciar sem renunciar a si mesmo" (Ms. E III 1, 3b-4a). 
os valores, e assim também o valor e o dever absoluto, são em última instância referidos a pessoas ${ }^{31}$.

No interior da sua ética de valores, mas também, sobretudo, ao pensar em teleologia, Husserl distingue entre valores hedonísticos ou sensíveis, cuja origem é prazer ou o apetecer, as emoções sensíveis - estes valores e bens são impessoais - e os valores superiores, espirituais, que são valores de pessoa e referidos sempre a pessoas; a origem destes é amor no sentido preciso da palavra, e eles implicam uma renuncia do prazer, ou a entrega ${ }^{32}$. Há, no fundo, um único dever absoluto que abarca ou realiza todos, e este é amor. Diz Husserl:

Todo o agir, todo o mirar é referido aos valores e, no fim, na medida em que é um agir absoluto, aos valores absolutos, isto são valores de pessoas e para pessoas. Finalmente tem tudo de fato valor apenas em relação às pessoas e valor absoluto em relação ao seu dever absoluto. Toda a verdade de valor é referida a pessoas, que se realizam no amor por elas, se elevam à 'perfeição'. A vida no dever absoluto é uma vida no amor puro que se dilata e cumpre, e viver assim é uma vida beata, não uma vida no gozo, mas vida no espírito e na verdade (Ms. A V 21, 14b).

Apenas a decisão por esta meta mais alta, que é o amor - e a sua práxis correspondente - pode realizar no Eu, na vida subjetiva, a unificação à qual ela tende em todas as esferas do ser. Apenas a vida a partir de amor é a vida que realiza a subjetividade humana enquanto pessoa; viver a partir de amor é viver autenticamente, a partir do seu núcleo pessoal e único. Por isso, o dever absoluto coincide com o amor. O que é exigido de mim por causa do amor pessoal - exigência que encontro profundamente em

31 Para Husserl, também o tema autêntico da ciência universal é em última instância o homem, a humanidade, referida ao seu mundo ambiente. Cf. Ms. A V 21, 72a.

32 "Valores hedonísticos têm a sua origem no prazer, em última instância em emoções sensíveis, e eles se realizam cada vez no prazer. Todo o aspirar de os produzir é o aspirar de eventualmente preparar ou possibilitar praticamente um tipo de prazer. Os valores da pessoa [...], como todos os valores especificamente "espirituais", brotam de fontes totalmente diferentes, das fontes de amor no sentido preciso. Nisto, o prazer do amor [Liebesgenuss] [...] é uma contradição. O amor - amando apaixonar-se pelo outro, viver no outro, unir-se com o outro, absolutamente não é hedonístico, embora funde alegria, alegria "elevada" (Hua XV, p. 406). 
mim mesmo, cuja realização coincide com o meu Eu pessoal verdadeiro - não pode ser arbitrariamente submetido à escolha, é incomensurável e incomparável com outros valores. Por isso, o amor é também dever mais íntimo e pessoal, chamado e vocação pessoal e neste sentido dever absoluto. ${ }^{33}$

$\mathrm{O} \mathrm{Eu}$ autêntico ama, amando está dedicado à sua meta autêntica e a sua preocupação [Sorge] é uma preocupação de amor. A vida autêntica é vida totalmente no amor, que por isso equivalentemente se chama vida no dever absoluto; o que quero, denomino também com as palavras "o que devo". Sigo uma exigência. Aqui sigo aquilo que totalmente pessoalmente me intima, e isto não é nada outro do que aquilo que eu amo no sentido mais profundo, o que no sentido mais profundo propriamente quero. A partir de mim mesmo e puramente a partir de mim mesmo não posso querer outro do que aquilo que eu absolutamente pessoalmente amo; amor é o voltar-se do Eu àquilo que o atrai absolutamente individualmente, enquanto este $\mathrm{Eu}$, e isto, se o tiver conseguido, seria para ele realização (Ms. A V 21, 90a).

A subjetividade decidida para o amor, para a perfeição maior é, como já mencionado, decidida para um fim infinito, no sentido de um fim não realizável completamente uma vez para sempre. Esta é a decisão para a eternidade, nas palavras de Husserl. Esta é a vontade no sentido próprio ${ }^{34}$. O homem vive na infinitude, diz Husserl ainda, porque nada de finito o pode realizar definitivamente e plenamente; a infinitude é por isso o seu

\footnotetext{
33 Em relação a outros valores objetivos Husserl diz que há uma hierarquia entre eles, no sentido de que os valores superiores realizam em si os inferiores e estes podem por isso ser substituídos. Quanto aos valores absolutos, não há comparação entre eles e não podem ser substituídos entre si; a não possibilidade de realização do valor absoluto pode ser apenas um sacrifício deste, renúncia, justificável unicamente em função de um outro valor absoluto. Assim, por exemplo, para mãe o filho é valor absoluto que não pode ser substituído por nenhum outro. "O bem ao qual se renuncia, que se sacrifica, permanece um valor de amor, um valor para mim, e enquanto individualidade pessoal estou em conflito comigo mesmo numa escolha deste tipo; ao sacrificar um bem, sacrifico a mim mesmo; e a dor do sacrifício é insuperável. Cada superior bem de amor para mim é superior por causa do sacrifício" (Ms. A V 21 81a).

34 "AvontadenoEuverdadeiro enuma comunidade verdadeira, numa humanidade verdadeira, é vontade no sentido "próprio", decisão [Entschlossenheit] para o fim absoluto enquanto reconhecido realizado na sua forma logicizada [logifizierten]. O fim na sua reconhecida eternidade, infinitude. A decisão, a vontade da infinitude, da eternidade" (Hua XV, p. 379).
} 
horizonte de vida constante, e ela implica um progredir constante, um elevar-se "in infinitum" de um ao outro valor e sua realização (Hua XV, p. 405). Mas a eternidade está implicada nas decisões e atos pessoais ainda de um modo diferente, segundo Husserl: enquanto a unificação da vida do Eu implica também a preservação do Eu no seu ser verdadeiro, fidelidade às decisões tomadas, isto exige do $\mathrm{Eu}$ - para que esta fidelidade seja possível, para que ela seja em função do seu ser autêntico - que o Eu faça decisões que possam ser mantidas para sempre, ou seja, decisões autênticas, para eternidade, ou em vista da eternidade ${ }^{35}$.

Contudo, o homem na sua facticidade - que pertence, contudo, à sua essência -, na sua falta da liberdade ética, também reconhece que a infinitude da exigência ética implica sempre a imperfeição atual. Por isso, Husserl afirma: "Eu posso apenas tornar-me bom e não ser-bom, e eu posso tornar-me bom apenas no querer-tornar-me-bom" (Ms. E III 1, 3b). As contradições e divisões pessoais, o decair do caminho em direção à meta, são parte da vida pessoal. Contudo, "a vontade do acordo" (Hua XXXIV, p. 366), da unidade, portanto da preservação do Eu pessoal, é a aspiração que rege toda a vida intencional. Por ela se constitui a identidade pessoal (BEJARANO, 2005, p. 315ss). A sua realização radical implica uma renovação, uma autocrítica ética do ponto de vista da exigência absoluta, como vimos. A autorreflexão radical, em níveis sempre mais altos, é uma condição para isto.

Ora, isto deve ser ainda completado. A subjetividade transcendental, na sua autoconstituição, implica necessariamente o mundo, e com ele outros homens, a intersubjetividade ${ }^{36}$. Isto pode ser claramente compreendido já

35 Neste sentido, Husserl escreve em Erste Philosophie: "Um cientista sabe-se membro de uma comunidade contínua sem fim, o seu produto não é propriedade meramente sua e de alguns acidentalmente co-interessados. Trata-se de uma verdade que deve continuar a valer na aprovação e compreensão de todos os cientistas futuros - para toda a eternidade. A vocação da vida do cientista vale a produção de valores 'eternos', que devem resistir a toda crítica possível de gerações futuras. Cada cientista futuro é igualmente interessado na autenticidade da verdade, que está na sua sempre igual acessibilidade [Erzielbarkeit] originária e necessária" (Hua VIII, p. 204).

36 "Subjetividade transcendental sendo na forma a ela necessária da mundanidade [Weltlichkeit], portanto na forma de uma humanidade que quer formar a si mesma e com 
a partir da consideração da intencionalidade do conhecimento, e vale tanto mais se levamos em consideração a pressuposição necessária do mundo da vida e da vida prática nele ${ }^{37}$. O processo do devir, autoconstituição da subjetividade é ao mesmo tempo a constituição do mundo e de uma comunidade. Por isso, a decisão ética significa a decisão de agir no mundo de um determinado modo ou, do ponto de vista transcendental, de constituir um mundo tal no qual os valores mais dignos sejam realizados, vividos.

Não pertence necessariamente a isto que o homem, ultimamente consciente de um nível mais alto, que aspira ao encontro da humanidade 'autêntica' [...] para isto concebe a idéia de um mundo teleologicamente verdadeiro, com homens autênticos (no sentido ideal) como homens verdadeiros, e reconhece esta idéia como telos infinito necessário do seu mundo de experiência que nele se constitui [...], que portanto necessariamente deve ser e em relação ao qual todo o mundo temporário - o mundo circundante universal de homens cada vez presentes (ou sujeitos transcendentais) - seria aproximação. Mas o ideal teleológico 'mundo', isto é, transcendental, este ideal da subjetividade concretamente constituinte é temporalizado; ele é uma idéia, no entanto, de uma comunidade intersubjetiva 'absolutamente perfeita' [...], porém encontrando-se totalmente no infinito. Todas as aproximações possíveis no estádio da [já] desperta consciência da meta da humanidade autêntica (autoconsciência do telos 'Eu enquanto Eu autêntico', e assim para a humanidade), são o progredir através da liberdade (Ms. E III 1, 3a).

A noção do ser verdadeiro ou autêntico se alarga, com isso, para o ser da humanidade verdadeira e autêntica e para um mundo que seja de acordo com este ideal, um mundo no qual os valores mais altos possam ser vividos e realizados. Estes são a humanidade e o mundo éticos ${ }^{38}$. Também

isso formar o seu mundo em mundo verdadeiro, "sem contradição" (Hua XV, p. 378).

37 "A existência [Dasein] humana singular, enquanto surgindo generativamente e transcorrendo no nexo generativo, não conhece nenhuma vida isolada, operativa; cada intenção e fazer do homem singular tem no seu horizonte outros, co-sujeitos e suas intenções e fazeres reais e possíveis" (Hua XXIX, p. 382).

38 "Portanto, um novo mundo, um novo mundo verdadeiro e uma nova humanidade 
neste sentido, a meta encontra-se no infinito, implica um processo e um progresso intersubjetivo infinito. Isto significa também um aprofundamento da noção da unificação que está relacionada à meta autêntica da vontade em última instância, a unificação pessoal é uma aproximação da unificação mais exigente, a dos homens numa comunidade ética. ${ }^{39}$ A exigência da unificação e do acordo não é apenas uma questão da vida pessoal, mas está intrinsecamente relacionada com a intersubjetividade e com o mundo comum. De fato, já a coerência do conhecimento objetivo, verdadeiro, do mundo pressupõe um acordo intersubjetivo, no sentido de concordância das percepções e dos juízos, a unanimidade [Einstimmigkeit]. O ser objetivo, verdadeiro, do mundo é o ser para todos. Por isso, Husserl diz que o acordo pessoal é possível apenas em comunidade, e isto não significa apenas uma justaposição de vontades individuais, mas a assunção, por parte de cada um, do aspirar de outro, de todos, como a minha responsabilidade pessoal.

Eu posso chegar à unanimidade [Einstimmigkeit] apenas numa comunidade com o outro [...], na qual cada um, pessoalmente aspirando à unanimidade como um Eu, aspira à unanimidade comigo e eu com ele. A comum-unanimidade não é a soma de unanimidades pessoais separadas, mas é apenas possível numa intenção (vontade) constante, na qual eu, aspirando à minha própria unanimidade, assumo pessoalmente [ichlich] a de todos os outros, a faço "meu próprio problema" e vice versa (Hua XXXIV, p. 362-363).

Cada homem que reconhece a exigência de tal meta, reconhecese "funcionário" da humanidade inteira. Neste sentido, é interessante a afirmação de Husserl de que a responsabilidade pessoal diz respeito a toda humanidade, ou seja: quem reflete sobre si mesmo reconhece que deve responder por todos os outros na medida em que interage na vida com eles;

verdadeira devem devir [...]. A verdadeira humanidade seria uma humanidade puramente ética e o mundo verdadeiro seria um mundo ético verdadeiro. Ele o é, porém, quando também cada vez é um mundo verdadeiro também sob aspecto lógico e estético" (Hua XXXVII, p. 318).

39 "Idéia da perfeição infinita, idéia do ser perfeito singular subjetivo no interior de uma comunidade [Allgemeinschaft] intersubjetiva infinitamente perfeita" (Hua XV, p. 379). 
e isto significa, segundo as palavras de Husserl, ter que responder também pela responsabilidade dos outros.

A auto-responsabilidade do único, que se sabe membro e funcionário da comunidade, [...] encerra consigo uma responsabilidade pela própria comunidade. Minha auto-responsabilidade estende-se dentro de todos os outros (e eventualmente em responsabilidades deles), com os quais colaboro ou sobre os quais ajo ou quero agir, e vice versa. Cada um é co-responsável por cada sua decisão e ato e pelos de todos os outros, embora em medida variável: quanto eu de algum modo poderia agir, ajo ou pude agir, sobre ele ou num plural social, sobre uma maioria ou totalidade, tanto posso e devo responder. Por outro lado, nesta ligação real ou possível, pertence à minha auto-responsabilidade que eu devo chamar também os outros a esta responsabilidade... (Hua VIII, p. 197198).

Isto é particularmente incisivo quando levamos em consideração que o acordo ou unanimidade não é apenas a do conhecimento objetivo, mas da vida ética que, contudo, pressupõe de algum modo o conhecimento verdadeiro do mundo. Esta unificação certamente é uma meta no infinito, ela, porém, com o seu horizonte presente e futuro infinito, motiva as decisões e o agir no presente ${ }^{40}$.

Que esta responsabilidade pelos outros e pela comunidade significa o amor - que o amor ao próximo, segundo Husserl, está implicado no amor por si mesmo e que por isso a procura de preservar o próprio ser significa ao mesmo tempo a cura pelo outro, deixa compreender-se claramente a partir das seguintes palavras de Husserl:

\footnotetext{
40 "A subjetividade transcendental pode ser apenas enquanto realizando suas possibilidades - aquelas possibilidades, nas quais ela se constitui ativamente numa identidade, que é por sua vez uma idéia, um pólo e um sistema-pólo. Correlativamente, a constituição de um mundo idêntico humanizado enquanto idéia no progresso infinito. $\mathrm{O}$ homem, a humanidade, apenas é na vontade de ser, de ser verdadeiro enquanto pessoa autêntica. A fenomenologia torna evidente que a humanidade tem uma essência absoluta, que ela pode descobrir sendo puramente em si para si, e que é no seu próprio ser apenas como horizonte, isto é, enquanto sendo nas suas possibilidades" (Ms. A V 22, 18a).
} 
Pois assim como para mim o outro está presente [vorhanden], para o Eu está presente o Tu, assim também a meta individual de procurar a si mesmo e de, chegando à clareza sobre si mesmo, realizá-lo em si, contém de certa maneira necessariamente a meta de procurar o outro e de ajudar praticamente ao outro a chegar ao seu si mesmo verdadeiro; isto, porém, apenas através dele mesmo e através do seu procurar-a-simesmo e formar-a-si-mesmo. Com outras palavras, na meta do amor próprio verdadeiro enquanto procura amorosa e criação despertada de si mesmo verdadeiro, está inclusa a meta do amor verdadeiro ao próximo, que serve ajudando ao próximo no seu procurar-a-si-próprio e formar-novamente-a-si-próprio (Hua XXXVII, p. 240-241).

\section{III}

O ser da subjetividade é um processo de constituição - ou também de renovação, como Husserl diz - de si mesmo - "A auto-constituição da subjetividade transcendental enquanto ser orientado no Infinito para 'Plenitude', para a verdadeira auto-conservação" (Hua XV, p. 378) ${ }^{41}$. Este processo é essencialmente voluntário, e com isto se torna compreensível o significado do alargamento da noção da vontade como caracterizando a totalidade da vida da consciência. A vontade pode de algum modo ser compreendida como implicada nas aspirações passivas da intencionalidade, e em todos os atos do conhecimento e da constituição do mundo; no seu

\footnotetext{
41 Na Krisis, Husserl se exprime de modo semelhante sobre o ser como um devir em direção à formação da pessoa ética, na sua correlação com a comunidade: "Razão é o específico do homem, enquanto ser [Wesen] que vive em atividades e habitualidades pessoais. Esta vida, enquanto pessoal, é um constante devir numa constante intencionalidade do desenvolvimento. O que nesta vida devém é a própria pessoa. O seu ser é sempre devir [Werden], e isto na correlação de ser singular-pessoal e comunidade-pessoal [gemeinschaftspersonalen] vale para ambos, para o homem e para a humanidade unitária. A vida pessoal humana percorre em níveis de auto-reflexão e auto-responsabilidade, a partir dos atos desta forma singulares, ocasionais, até o nível da auto-reflexão e autoresponsabilidade universais, e até a compreensão consciente da ideia da autonomia, da ideia de uma decisão da vontade de formar a própria vida pessoal total na unidade sintética de uma vida na auto-responsabilidade universal; correlativamente, de formar a si mesmo num $\mathrm{Eu}$ verdadeiro, livre, autônomo, que procura realizar a razão que lhe é inata, a aspiração de permanecer fiel a si mesmo, de poder permanecer idêntico consigo mesmo enquanto Eu da razão; isto, porém, na correlação inseparável para pessoas singulares e comunidades, em função da sua ligação imediata e mediata em todos os interesses - ligados em acordo e contradição - e na necessidade de fazer chegar à realização sempre mais perfeita a razão individual apenas enquanto comunitário-pessoal, e vice versa" (Hua VI, p. 272-273).
} 
nível mais alto, porém, a vontade é a decisão livre para a meta mais alta da vida, para o valor mais alto que determina a totalidade da vida pessoal, e que é a formação de si mesmo como pessoa, enquanto coerente consigo mesmo e em comunhão com a comunidade.

Podemos agora concluir algo a respeito da teleologia, retomando as afirmações de Husserl de que a teleologia é primeiramente a teleologia do ser da subjetividade transcendental. O ser da subjetividade, precisamente quando esta é orientada conscientemente para a ideia da sua realização no infinito, para o seu telos, quando este se torna a sua meta pessoal, é o "ser no sentido da vontade" (Hua XV, p. 381) (2) $^{42}$ e a teleologia é a sua forma ontológica, diz Husserl:

Esta tendência de desenvolvimento [Entwicklungszug] e processo de desenvolvimento é ordenado enquanto função na tendência universal da unidade [Einheitszug] e tendência do desenvolvimento da teleologia, que constitui o ser universal da subjetividade transcendental enquanto forma ontológica (Hua XV, p. 378).

Isto, contudo, exige ulteriores esclarecimentos. Ser é um processo teleológico da subjetividade que tem no seu horizonte toda a humanidade e é, portanto, de algum modo, relacionado ao ser da intersubjetividade transcendental. A intersubjetividade está sempre no horizonte da subjetividade transcendental; já o eidos do Eu implica em si eideticamente a humanidade e as suas implicações mútuas. Ora, ser é, como lemos, ser no sentido da vontade. Talvez aqui o alargamento da noção da vontade para todas as dimensões da consciência alcance o seu sentido mais profundo. Ser é o ser orientado, da vontade, para a sua meta, para o seu telos, é o tender da vontade para a sua meta. A vontade, sobre a qual o telos "age" como motivo, como aspiração, como a sua tendência e seu fim, tem um horizonte latente que, pela descoberta na reflexão e pela decisão pessoal, pode tornar-se vontade patente, ou desperta, a decisão no sentido próprio

\footnotetext{
42 "Ser tem aqui o sentido da existência [Dasein] transcendental, da existência [Dasein] de uma subjetividade (da personalidade individual concreta na sua vida), que sendo, vive na vontade de ser em autenticidade, no acordo sem contradições. Isto é ser no sentido da vontade [Sein im Sinn des Willens]" (Hua XV, p. 381).
} 
pelo ser verdadeiro. Isto significa que o telos é desencoberto e assumido, tornado patente, ele reúne em si e unifica todos os outros objetivos.

Este processo teleológico, o processo de ser da intersubjetividade transcendental, traz em si uma universal - primeiramente nos sujeitos singulares escura - "vontade de viver", ou melhor, vontade do ser verdadeiro (talvez possamos dizer, a vontade respectiva na sua forma patente, tem um "horizonte de vontade" latente). No desenvolvimento, ela se torna patente primeiramente no sujeito singular, ou a partir do horizonte aberto-vazio, não-formado, torna-se um formado, o homem despertado no seu transcendental, nele desperta o horizonte da autêntica humanidade. Nele se encontra esta idéia enquanto formada pré-ontologicamente, como aquela, que no desenvolvimento ulterior através da reflexão na figura da ontologia conserva a forma científica e enquanto idéia ontológica pode tornar-se dominante para a vontade, que tem deste modo a sua meta explícita, respectivamente a explícita forma da meta, a forma do objetivo da totalidade de todos os objetivos individuais e supra-individuais (intersubjetivos, omni-humanos) (Hua XV, p. 378-379).

Este horizonte latente pode ser compreendido, por um lado, como a implicação intencional da intersubjetividade transcendental - da humanidade autêntica, portanto da ideia da humanidade infinitamente perfeita da qual faço parte no infinito e à qual estou chamado a participar como o seu realizador - na subjetividade transcendental; ou, a implicação do fim, do ideal da humanidade perfeita. Esta implicação é primeiramente latente, obscura - uma obscura vontade de viver, nas palavras de Husserl, mas ela assume, na vida plenamente desperta, a forma explícita, pessoal, do meu objetivo que reúne todos os objetivos; é uma vontade metafísica, vontade com uma função transcendental de ser a motriz, a mola propulsora da vida intencional - "vontade universal transcendental"43. A vontade transcendental universal desperta é, nas palavras de Husserl, "o despertar da Omnisubjetividade" na subjetividade, como um alargamento universal da vontade. Ela é o tornar-se desperto da teleologia, como a forma do ser

43 O sentido da verdade [Wahrheitssinn] que vive nela, é nela vontade universal transcendental escondida, (a vontade "metafísica" de ser) e nela se torna vontade desperta nos graus de vigília, no alargamento singular e extensivo-intensivo (Hua XV, p. 379). 
da subjetividade (Hua XV, p. 380) ou, como podemos também dizer, a forma do seu devir. ${ }^{44}$ Para Husserl, como já vimos, há um entrelaçamento teleológico entre o indivíduo e a comunidade; a comunidade pois, não é apenas uma soma de indivíduos, mas uma unidade de nível superior, que tem o seu próprio ser e a sua própria ideia teleológica. $\mathrm{O}$ telos individual não apenas não pode ser em contradição com a vida e a meta mais alta da comunidade, mas as vontades pessoais são chamadas a unir-se na comunidade de vontade, o telos individual realiza o telos da comunidade e vice versa, a teleologia universal torna-se um momento do telos individual, quando ela se torna consciente, esclarecida e assumida pelos indivíduos (MELLE, 1991, p. 133). A realidade do ser da intersubjetividade transcendental, o seu ser real na subjetividade individual, é possível apenas na forma da vontade de ser, na forma do poder ser voluntário (Hua XV, p. 381). Este é, portanto, o ser no sentido da vontade. Com isso, a humanidade no seu ser histórico, no seu processo de desenvolvimento histórico, que é um desenvolvimento teleológico, pode ser pensada ${ }^{45}$.

44 Esclarecer este conceito, a meu ver difícil, de Allsubjektivität, ultrapassa o objetivo deste trabalho. Husserl o menciona num texto complementar da Krisis, chamando-o também de omni-comunidade [Allgemeinschaft], Nós-Todo [Wir-All]; o conceito está relacionado à questão da constituição do mundo, num processo não somente subjetivo, mas intersubjetivo. A Omni-subjetividade, a totalidade das subjetividades transcendentais, tem como correlato o mundo; a sua forma é a temporalidade intersubjetiva. De fato, a questão de uma unidade mais alta, superior à subjetividade transcendental, surge a partir da questão da constituição do tempo objetivo que não pode ser constituído unicamente numa subjetividade transcendental singular, pois implica todos os fluxos subjetivos de vivência. "Observada totalmente, a Omni-subjetividade transcendental é totalidade sendo absolutamente, um absoluto que é na sua forma de essência um 'ens a se', pelo que este 'ens' é a totalidade de entia singulares transcendentais, nomeadamente de entia, que a seu modo têm novamente a forma 'ens a se'. Este ser-'a-se' significa, que ela é ao mesmo tempo constituinte e constituída, como constituindo-se a si mesma. Deste modo também o tempo é forma desta totalidade, que dá posição a cada sujeito singular, sem a qual ele é impensável (já que é pensável unicamente na Totalidade), pertence-lhe necessariamente como à autoconstituição" (Hua XXIX, p. 80-81). Penso que não se deve confundir este conceito com o Allbewusstsein e do Monadenall, que será por Husserl relacionado a Deus.

45 Cf. LO, 2002, p. 196. Bejarano (2005) identifica o horizonte latente da vontade e do telos. Assim como a vontade, segundo este autor, uma vez compreendida na sua universalidade, age em níveis diferentes da vida da consciência - na passividade, na constituição do mundo pelo conhecimento, na decisão pessoal a respeito da própria existência, - assim também a teleologia. Penso que esta identificação sem mais não se sustenta. Telos não é o próprio horizonte, mas o que a partir do horizonte da vontade a motiva, impulsiona, dá força, orienta. 
Ora, um passo ulterior e, a meu ver, decisivo para a compreensão da teleologia, é feito por Husserl ao se perguntar pela origem deste telos que é descoberto no horizonte do ser da subjetividade. A subjetividade pode, pois, conscientemente e livremente pôr as metas para a própria ação e para a totalidade da vida, mas não pode pôr arbitrariamente o telos, a aspiração originária que descobre em si, a tendência à unificação da sua vida pessoal com a de todos os homens, tendência ao Infinito e ao absoluto como o desenvolvimento e a renovação em direção à perfeição ética de amor e a responsabilidade para a realização desta aspiração ${ }^{46}$. A exigência do esclarecimento último da origem da teleologia coloca Husserl, assim, perante a pergunta sobre Deus. As suas afirmações a respeito disso não estão ausentes de problemas, que não podem ser abordados aqui ${ }^{47}$, mas é necessário apenas apontar para a orientação que assumem as suas investigações a respeito desta questão. Ele diz explicitamente que a vontade universal absoluta que vive em todos os sujeitos transcendentais é a vontade divina (Hua XV, p. 381) e em vários contextos afirma que Deus governa o mundo (Hua VIII, p. 258). Deus deve ser pensado como

a fonte de todo o ser e o princípio de todos os desenvolvimentos no mundo, princípio da constituição de um mundo de acordo com as leis, orientado para os valores, realizando os valores. Através do meu coração, através da pulsação da minha vida vai a vida divina, o amor de Deus e o amor do mundo (A V 21, 47a). O amor divino, que vive em todos aqueles que amam no sentido puro, que amam a si mesmos e o próximo (Ms. A V 21, 19a).

Estas conclusões, contudo, não podem ser tomadas, a meu ver, como resolvendo para o autor de modo fácil a questão do sentido. Nos escritos do último período da vida de Husserl, nomeadamente depois da

\footnotetext{
46 Isto é particularmente evidente na argumentação de Husserl, que não pôde ser abordada aqui, sobre a presença da teleologia na dimensão passiva da vida da subjetividade, na temporalização do fluxo originário, nos instintos, no Factum da subjetividade com todo o seu material hylético, pressuposto na vida ativa do Eu livre e consciente, como o seu pré-ser... A teleologia é num sentido anterior ao Eu, embora ela pressuponha o seu Factum. "Com este estado de coisas, diz Husserl, pode se dizer que esta teleologia, com a sua facticidade originária, tenha o seu fundamento em Deus?” (Hua XV, p. 385).

47 Estes problemas dizem respeito, a meu ver, principalmente à questão da transcendência ou imanência de Deus no ser da subjetividade ou intersubjetividade, e isto talvez seja devido ao perigo nunca definitivamente resolvido do idealismo no pensamento de Husserl.
} 
primeira guerra mundial e, sobretudo, nos anos 1930 - período histórico que foi difícil para a Europa, para a Alemanha e pessoalmente para Husserl que certamente não pôde não sentir-se apelado pela situação do seu povo - encontramos reflexões que revelam uma dolorosa confrontação com a questão do mal, do sofrimento e da morte, da desnaturação do povo, do acaso e aparente irracionalidade do destino. Através disso, a questão do sentido, e com isso da teleologia e da vontade, assumem aspectos novos. Para que a vida humana no mundo, que aparece ser irracional por causa do sofrimento e do mal, seja possível, é necessário que tudo tenha um sentido, que tudo seja em última instância orientado para o sentido, isto é, para um bem definitivo; é necessário que o mundo seja um mundo em que haja teleologia e em que Deus governe a história através dos atos livres dos homens em direção ao Bem. Para que a vida humana seja possível - isto quer dizer, para que a vida possa ser racionalmente conduzida, decidida, para que o amor possa ser optado e permanecer o valor mais alto num mundo em que tudo parece ser contrário ao amor, diz Husserl. A questão do sentido é em si mesma, em última instância, uma questão da decisão pessoal; para que esta decisão possa ser feita, é necessária a fé. A própria fé em Deus que garante sentido humano ao mundo e à história é uma exigência para a possibilidade da vida racional e sensata no mundo, a exigência absoluta e mais alta, diz Husserl.

Mas, como isto pode ser compreendido de outro modo do que sob a ideia de Deus? De que outro modo, do que de que através de todo o Eu e vida do Eu, através de toda a consciência reina uma teleologia [...] de modo semelhante como um ente pessoal nas suas exigências pessoais nas almas - eu posso apenas ser feliz, eu posso apenas sê-lo em todo o sofrimento, infelicidade, em toda a irracionalidade do meu mundo circundante, se acredito, que Deus é e que este mundo seja um mundo de Deus, e quero com toda a força da minha alma segurar o dever absoluto, e isto é em si um querer absoluto, então devo absolutamente crer, que Ele seja. A fé é a exigência absoluta e mais alta (Ms. A V 21, 15b). ${ }^{48}$

\footnotetext{
48 'O mundo deve ter um 'sentido', em todo o destino do homem singular e do povo deve estar um sentido unitário e compreensível. A filosofia deve construir o sentido em relação à irracionalidade do fato. Este é irracionalidade frente à racionalidade teórica [...]. $\mathrm{O}$ que deve ser acreditado, para que o mundo possa ainda ter um sentido, para que nele a vida humana possa permanecer razoável. O conteúdo da fé jamais é justificável através do conhecimento ,teórico', mas a fé é justificável [begründbar] a partir do motivo de uma possível vida racional prática” (Ms. A V 21, 21b).
} 
A fé é a exigência mais alta, porque de algum modo torna possível todas as outras opções. Deus não conduz o mundo para um fim feliz da história, segundo Husserl, mecanicamente ou espontaneamente, como uma força exterior à própria consciência livre das pessoas; os homens são irredutivelmente livres, enquanto ainda têm alguma possibilidade prática de agir e de decidir sobre a sua própria vida, por isso eles mesmos decidem sobre o seu fim e sentido. ${ }^{49} \mathrm{O}$ indivíduo permanece por isso ultimamente responsável pela afirmação e realização do sentido. A fé na existência da teleologia que tem fundamento em Deus é a decisão pessoal necessária frente à exigência do sentido e da possibilidade da vida humana livre e ética num mundo em que tudo parece ocorrer de forma contrária ao bem e ao amor, é o que deve ser criado para que haja o sentido humano. Apenas a partir da fé se pode compreender e reconhecer a teleologia.

Apenas sob a pressuposição desta fé a minha vida ganha um sentidofim e pode permanecer mantida de modo razoável, e conserva a força de impulso e o valor que aumenta necessariamente. Apenas assim

49 "A ordem moral do mundo - isto significa: o Eu se sabe livre, na medida em que tem cada vez seu campo de possibilidades práticas, ou melhor, na medida em que pode decidirse, ali onde está convencido que tem estas e estas possibilidades práticas" (Ms A V 21, 80a)." Como sempre, uma vez podem desmoronar todas as esperanças, pode chegar a morte $[\ldots]$ a humanidade pode abandonar o verdadeiro, decair para o animal, ou para a pior degeneração, pode desmoronar tudo o que lhe dá valor para nós - eu vivo, tenho ainda um horizonte de vida, tenho ainda possibilidades do fazer autêntico, embora ao lado de acasos irracionais que pertencem a cada momento futuro como possibilidades abertas, agora como indeterminadas, imprevisíveis. | Eu vivo como devo, faço o que tenho agora a fazer, cumpro a ordem da hora. Não desvio o olhar destes não-sentidos, levo os conscientemente em consideração, ao olhar para eles assumo-os e os aceito no meu 'Eu quero'; não obstante eles, faço o que posso e exclusivamente o que devo. Não significa isto: sacrifico conscientemente a fé bonita na cegueira irrefletida para o destino, e com isso o bem mais alto que era para mim o mundo, enquanto deveria ser tornado mais belo através de mim, e para nós todos, enquanto o mundo de beleza. | Ou melhor: reconheço como aparência a meta prática universal, que para mim até agora valia como a meta da vida humana autêntica - e contudo: não abdico do autêntico, quero permanecer fiel a mim mesmo, e nisto está: eu quero viver de tal modo, como se a meta ainda fosse possibilidade prática. Ela não pode ser mais para mim a meta na sua infinitude. Mas eu sou e nós somos, e na atualidade da nossa vida permanece o horizonte da vida como legítimo, mesmo que antecipação indeterminada. Nisso temos um percurso de desenvolvimento humano vivo e a ele dedicamos a nossa força, até onde ele alcança, enquanto possibilidade prática para o reconhecer e depois para realizá-lo conscientemente: no nosso amor" (Ms. A V 21, 91a-91b). 
há experiência teleológica e argumentação teleológica a respeito de uma teleologia de mundo: para poder reconhecer o reinar de Deus, devo já acreditar em Deus. Para poder acreditar em mim e no meu Eu verdadeiro e no desenvolvimento em direção a ele, devo acreditar em Deus e na medida em que o faço, vejo a condução divina, o conselho de Deus, a solicitação divina na minha vida (Ms. A V 21, 24b-25a).

A unificação da vida pessoal, a descoberta do Eu pessoal mais verdadeiro, a partir do qual posso reconhecer e também realizar o amor como a exigência pessoal absoluta para que haja sentido na minha vida e na vida da humanidade, é apenas possível a partir da fé no sentido do mundo em Deus. Por isso o indivíduo, sabendo se responsável pelo sentido do mundo, deve decidir pela fé e pelo sentido, precisamente frente à irracionalidade da história e frente ao sofrimento, por causa do destino comum da humanidade, pela realização do sentido não apenas na sua vida pessoal, mas na vida da humanidade, pela qual deve responder. Pois frente à exigência da realização do sentido no meio dos acontecimentos sem sentido, o Eu sabe que apenas os seus atos podem fazer este sentido acontecer e superar o mal.

Conta-se sobre mim, sobre cada orientação boa em mim, sobre cada ato livre se conta. Nada é perdido, nunca estou perdido, e sobretudo a minha loucura [Wahnsinn], a minha morte, sobretudo a degeneração transitória do meu povo e o seu colapso, etc. Nada nisto é puro nãosentido, mas é o pressuposto para um bem mais alto. Tudo tem o seu bem, tudo serve, porém, tudo conta sobre mim e sobre cada um de nós, para que afirmemos a sua existência, mas neguemos o seu dever-ser e vivemos na fé, de que o nosso agir livre positivo na vocação tenha a força, no proceder sem-fim da vida humana, de superar o mal do mundo (Ms. A V 21, 98a).

Neste sentido, a fé pode ser compreendida como a própria força divina no homem e a vida da vontade de uma pessoa que decida a própria vida e personalidade de tal modo, é a vida em que Deus pode ser reconhecido no mundo. 
Eu vivo, eu devo poder viver, eu posso viver apenas na esperança, eu posso viver verdadeiramente apenas na vocação e na esperança que a pressupõe. A vida é o que é, enquanto vida da vontade, não é um mero fato no mundo, mas o mundo precede a minha vida e nele a minha vontade é motivada nas suas orientações de vontade necessárias. As condições de possibilidade de uma vontade unitária, na qual estou e posso ser unificado, nunca podem ser renunciadas [aufgegeben]. Não creio arbitrariamente, mas creio a partir da necessidade de ser Eu e membro da humanidade, de ser frente a meu mundo circundante respectivo como um voluntariamente-ativo [wollend-tätiger]. Não posso nada outro que crer e, no descobrimento de mim mesmo e do mundo, crer universalmente. A fé é força divina. Enquanto vivo na fé e vivo na orientação à minha vocação, vive em mim a força divina. Destino, portanto tribulação, produz a fé, e nela a superação do destino, mas juntamente com isso também superação da mundanidade mais baixa. Sobretudo onde a vida é vida no amor, no aspirar do amor, no aspirar para o que é devido e o que é acessível através do próprio amor, ali ela é "mundana", na medida em que se desvia das forças da irracionalidade (Ms. A V 21, 89b).

A fé é, segundo as palavras de Husserl, a condição de possibilidade de uma vontade unitária. Se foi dito no início que a vontade tem um caráter criador, é precisamente na decisão pessoal pela fé, pelo amor e pelo sentido e na dedicação da vida à sua realização, não obstante as contradições e semsentido do mal, é precisamente nesta decisão que a vontade parece revelar a sua força mais criativa e mais potente, abrindo para a humanidade uma temporalidade, um futuro em que o Bem se realiza, no meio das tribulações do mal no presente. E precisamente nesta decisão, parece para Husserl também realizar-se a teleologia: a pessoa pode realizar a sua verdade, a sua vocação, que é a de contribuir para realização do sentido na humanidade. A decisão pela fé pode ser interpretada também como aceitação da vocação pessoal e única, da parte da subjetividade, a aceitação do modo pessoal da realização da responsabilidade pelo destino do mundo, a qual o Eu pode reconhecer-se chamado, na sua consciência pessoal e íntima, sabendo que não é ele mesmo a origem desta vocação. 
Se podemos agora concluir esta interpretação da teleologia, podemos dizer que o telos está latentemente presente no ser da subjetividade, no seu ser da vontade, como aspiração fundamental à perfeição infinita que se torna explícito pela decisão filosófica, ética, da renovação para o ser verdadeiro e autêntico, para o amor. A teleologia do ser não se realiza espontaneamente e mecanicamente, não opera de fora da subjetividade, mas se realiza através da decisão pessoal e livre do $\mathrm{Eu}$ - que se torna autêntico e livre precisamente ao assumir em si esta aspiração como a sua meta pessoal. A fé na existência e realização do sentido em Deus, a fé na possibilidade da realização do bem não obstante o mal e a contradição presente, a aceitação da vocação pessoal a contribuir para a realização do sentido no mundo, é uma condição de possibilidade para esta opção pessoal, por isto ela é a primeira exigência, e neste sentido a mais alta. Nela a vontade ultimamente é unificada.

Resta, a meu ver, a pergunta pela condição de possibilidade da fé, ou seja, a partir de textos mencionados aqui não se pode esclarecer como a subjetividade pode crer nas situações desumanas de mal e sofrimento. A presença do telos no ser da subjetividade, a teleologia do ser, portanto, é um modo de abertura do ser ao Infinito que esclarece o sentido. A vontade como fé, como a opção gratuita pelo amor, é certamente um modo de o Infinito, Deus,revelar-se no ser da subjetividade. Seria possível esclarecer esta relação entre ser e Infinito ainda mais originariamente, como tornando possível a decisão da vontade subjetiva? Provavelmente a decisão da subjetividade não é absolutamente o primeiro momento desta relação, mesmo na subjetividade. Aliás, Husserl fala da subjetividade transcendental como um fato absoluto que encerra em si, na sua própria facticidade, já a teleologia; a vontade pode realizar o telos, mas ela mesma também já está encerrada e tornada possível pela mesma realidade que é a origem da teleologia. Esta seria a pergunta pelo sentido último do ser na sua relação com o Infinito. Além disso, o que deve ser a filosofia, na forma da époche radical ética e, portanto, não mais teórica, mas prática, o colocar-se pessoal perante o Infinito, para que a opção pessoal pelo sentido seja possível? $\mathrm{Na}$ verdade, esta mudança radical, esta reflexão radical, não poderá ser filosofia no sentido tradicional, pois ela significa colocar-se inteiramente 
diante do Infinito do amor de Deus. Husserl talvez não consiga exprimir isto em termos que sejam radicalmente diferentes da sua orientação inicial, até a fé que condiciona o sentido é uma fé filosófica. Para Husserl, toda filosofia autêntica deve desembocar na teologia. A partir daqui coloca-se, a meu ver, a pergunta sobre a relação entre subjetividade e Deus.

\section{Referências}

BEJARANO, Julio C. Vargas. Phänomenologie des Willens. Seine Struktur, sein Ursprung und seine Funktion in Husserls Denken. Frankfurt am Main: Peter Lang, 2005.

CARR, David; LOTZ, Christian (Org.). Subjektivität - Verantwortung Wahrheit. Neue Aspekte der Phänomenologie Edmund Husserls. Frankfurt am Main: Peter Lang, 2002.

FINK, Eugen. Die Spätphilosophie Husserls in der Freiburger Zeit“". In: . Edmund Husserl (1859-1959), La Haye: Martinus Nijhoff, 1959,

p. $99-115$.

GOTO, Hiroshi. Der Begriff der Person in der Phänomenologie Edmund Husserls. Ein Interpretationsversuch der Husserlschen Phänomenologie als Ethik im Hinblick auf den Begriff der Habitualität. Würzburg: Könighausen\&Neumann, 2004.

HOHL, Hubert.Lebensweltund Geschichte. Grundzüge der Spätphilosophie E. Husserls. Freiburg-München: Karl Alber, 1962.

HOYOS VÁSQUEZ, Guilhermo. Intentionalität als Verantwortlichkeit. Geschichtsteleologie und Teleologie der Intentionalität bei Husserl. Den Haag: Martinus Nijhoff, 1976.

HUSSERL, Edmund. Aktive Synthesen: Aus der Vorlesung 'Transzendentale Logik' 1920/21 Ergänzungsband zu 'Analysen zur passiven Synthesis' (Husserliana XXXI) Roland Breeur (Hrsg.). The Hague, Netherlands: Kluwer Academic Publishers, 2000.

- Analysen zur passiven Synthesis. Aus Vorlesungs- und Forschungsmanuskripten, 1918-1926. (Husserliana XI). Margot Fleischer (Hrsg.). The Hague, Netherlands: Martinus Nijhoff, 1966. 
Aufsätze und Vorträge. 1911-1921. Mit ergänzenden Texten (Husserliana XXV). Thomas Nenon and Hans Rainer Sepp (Hrsg.). The Hague, Netherlands: Martinus Nijhoff, 1986.

.Die Krisis der europäischen Wissenschaftenund die transzendentale

Phänomenologie. Eine Einleitung in die phänomenologische Philosophie (Husserliana VI). Walter Biemel (Hrsg.). The Hague, Netherlands: Martinus Nijhoff, 1976.

.Die Krisis der europaischen Wissenschaftenund die transzendentale Phänomenologie. Ergänzungsband. Texte aus dem Nachlass 1934-1937 (Husserliana XXIX). Reinhold N. Smid (Hrsg.). The Hague, Netherlands: Kluwer Academic Publishers, 1992.

. Einleitung in die Ethik. Vorlesungen Sommersemester 1920 und 1924 (Husserliana XXXVII). Henning Peucker (Hrsg.). Dordrecht, Netherlands: Kluwer Academic Publishers, 2004.

. Einleitung in die Philosophie. Vorlesungen 1922/23 (Husserliana XXXV). Berndt Goossens (Hrsg.). Dordrecht, Netherlands: Kluwer Academic Publishers, 2002.

- Erste Philosophie (1923/4). Zweiter Teil: Theorie der phänomenologischen Reduktion (Husserliana VIII). Rudolf Boehm (Hrsg.). The Hague, Netherlands: Martinus Nijhoff, 1959.

. Formale and transzendentale Logik. Versuch einer Kritik der logischen Vernunft. (Husserliana XVII). Paul Janssen (Hrsg.). The Hague, Netherlands: Martinus Nijhoff, 1974.

. Phänomenologische Psychologie. Vorlesungen Sommersemester.

1925 (Husserliana IX).Walter Biemel (Hrsg.). The Hague, Netherlands: Martinus Nijhoff, 1968.

. Vorlesungen über Ethik und Wertlehre. 1908-1914 (Husserliana XXVIII). Ullrich Melle (Org.). The Hague, Netherlands: Kluwer Academic Publishers, 1988.

. Zur Phänomenologie der Intersubjektivität. Texte aus dem Nachlass. Dritter Teil. 1929-35 (Husserliana XV). Iso Kern (Hrsg.). The Hague, Netherlands: Martinus Nijhoff, 1973. 
. Zur phänomenologischen Reduktion. Texte aus dem Nachlass (1926-1935) (Husserliana XXXIV). Sebastian Luft (Hrsg.). Dordrecht, Netherlands: Kluwer Academic Publishers, 2002.

. Manuscritos não publicados: Ms. A V 21, Ms. A VI 34, Ms. B III 9, Ms. E III 1.

MELLE, Ullrich. "Husserls Phänomenologie des Willens", Tijdschrift voor Filosofie, Leuven, v. 54, n. 2, p. 280-304, Jun. 1992, . "The Development of Husserl's ethics", in: Études phénoménologiques, n. 13-14, Louvain, vol.7, 1991, p. 115-135.

NOOR, Ashraf. Individualitè et Volonté", in Études phénoménologiques, Louvain: vol.7, n. 13-14, 1991, p. 137-164.

SILES i BORRÀS, Joaquim. The Ethics of Husserl's Phenomenology. Responsibility and Ethical Life. London, New York: Continuum, 2010.

STRASSER, Stephan. "Das Gottesproblem in der Spätphilosophie Edmund Husserls“, Philosophisches Jahrbuch, München, v. 67, p. 130 - 142, 1958,.

STRASSER, Stephan. „Der Gott der Monadenalls. Gedanken zum Gottesproblem in der Spätphilosophie Husserls“, Perspektiven der Philosophie, Amsterdam, v. 4, p. 361 - 377, 1978.

Data de registro:01/10/2011

Data de aceite:28/03/2012 